\title{
PEMILIHAN UMUM ANGGOTA PARLEMEN DALAM PERSPEKTIF KESETARAAN DAN KEADILAN GENDER DI INDONESIA
}

\author{
Ratna Riyanti \\ Universitas Pancasakti Tegal, Indonesia, ratnariyanti662@gmail.com
}

\begin{abstract}
The issue of women's representation has gained a place since the implementation of the $30 \%$ quota in the 2004 elections, but until the 2014 elections the number of women in the national parliament decreased by 22 seats compared to the 2009 election. In the development of human resource development culture, the state actually does not look from a gender perspective for equality and everything. form of development facilities for human resources that are perfect for the purpose of developing the nation itself. It's just that in reality, the implementation appears to be predominantly male. This is because in addition to the Javanese culture of women, there is also limited public access for women, be it by customary norms, morals, politeness or legal norms. The affirmative action set forth in the election law from 2004 - 2019 has so far not been realized, this has led to a phenomenon in women's political rights. The issue that will be discussed is How the General Election of Parliamentary members from the perspective of gender equality and justice? The objectives of the issues raised are: to determine a general election that is gender-equitable and equitable. The type of research used is normative empirical. The data analysis used is a qualitative analysis that begins with the process of collecting data, simplifying data, presenting data and drawing conclusions. Whereas the results of the research on the representation of women in legislative institutions have not yet fulfilled the principle of equality and gender justice because in the current regulations regarding the establishment / formation of political parties, management, decision making, political recruitment, and political education paying attention to women's representation at least $30 \%$, there is no The rules regarding sanctions for political parties that do not meet these provisions, as well as affirmative policies in candidacy, and the placement of women in the candidate list, have not been as expected.
\end{abstract}

Keyword: Parliament, Elections, Gender Equality and Justice

\begin{abstract}
Abstrak
Isu keterwakilan perempuan memperoleh tempat sejak diterapkannya kuota $30 \%$ pada pemilu 2004, namun hingga berlangsungnya Pemilu 2014 jumlah perempuan di parlemen
\end{abstract}


nasional berkurang 22 kursi dibandingkan pemilu 2009. Dalam perkembangan kultur pembangunan sumber daya manusia, sebenarnya negara tidak memandang dari sisi gender untuk pemerataan dan segala bentuk fasilitas pembangunan untuk sumber daya manusia yang sempurna dengan tujuan pembangunan bangsa itu sendiri. Hanya saja dalam kenyataan pelaksanaannya justru kelihatan dominan hanya laki-laki. Hal ini disebabkan karena selain ada kultur budaya jawa tentang perempuan juga atas akses public bagi perempuan terbatas, baik itu oleh norma adat, susila, kesopanan maupun norma hukum. Affirmative action yang dituangkan dalam undang-undang pemilu dari tahun 2004 - 2019 sejauh ini belum dapat terwujud, hal ini menimbulkan suatu fenomena dalam hak-hak politik perempuan. Permasalahan yang akan dibahas adalah Bagaimana Pemilihan Umum anggota Parlement dalam perspektif kesetaraan dan keadilan gender? Tujuan dari permasalahan yang diangkat adalah : untuk mengetahui Pemilihan Umum yang berkesetaraan dan berkeadilan gender, Jenis penelitian yang digunakan adalah normative empiris. Analisis data yang digunakan adalah analisis kualitatif yang diawali dengan proses pengumpulan data, penyederhanaan data, penyajian data dan penarikan kesimpulan. Sedangkan hasil penelitian adanya keterwakilan perempuan di lembaga legislative belum terpenuhi adanya prinsip kesetaraan dan keadilan gender karena dalam regulasi yang sekarang ini mengenai pendirian/pembentukan partai politik, kepengurusan, pengambilan keputusan, rekrutmen politik, dan pendidikan politik memperhatikan keterwakilan perempuan minimal 30\%, belum ada aturan mengenai sanksi bagi partai politik yang tidak memenuhi ketentuan tersebut, demikian halnya kebijakan affirmatif dalam pencalonan, dan penempatan perempuan dalam daftar calon , belum seperti yang diharapkan.

\section{Kata kunci : Parlemen, Pemilu, Kesetaraan dan Keadilan Gender}

\section{A. Pendahuluan}

$$
\text { Perubahan banyak terjadi }
$$

dalam tatanan sosial maupun politik

dalam dua dasawarsa terakhir ini

dengan perkembangan

demokrasi modern di Indonesia.

Perkembangan demokrasi yang

berlandaskan pada Hak Asasi

Manusia ,Keadilan serta

Kesetaraan menuntut adanya

keterlibatan seluruh masyarakat.

Kesetaraan merupakan salah satu

tujuan demokrasi, $\quad$ khususnya kesetaraan laki-laki dan perempuan ${ }^{1}$.

Suatu negara yang menganut yang menganut demokrasi mempunyai

kewajiban untuk mewujudkan

kesetaraan, kesejahteraan dan keadilan bagi warga negara.

Kesejahteraan, Keadilan dan

Kesetaraan untuk rakyat miskin

maupun kaya, dan untuk laki-laki

maupun perempuan .

\footnotetext{
${ }^{1}$ Ahmad H. Silaban, Implementasi Politik Perempuan di Kota Makasar, dalam Jurnal Politics : Jurnal Magister IImu Politik Universitas Hasanudin, Vol. 1, Number 1, Januari 2015.
} 
Pada proses perkembangan

selanjutnya, kaum perempuann

diberikan hak untuk mendapatkan

kesempatan belajar secara formal

seperti kaum laki-laki dan begitu pula

perempuan juga dapat masuk ke dalam

ranah politik .

Banyak penolakan terhadap perempuan yang masuk dalam ranah politik, dengan alasan perempuan dipandang kurang mampu dalam melakukan pekerjaan yang sulit dan keras yaitu mengurus sebuah negara maupun masyarakat banyak. Menurut M.A Hardaker dalam bukunya Endang Suniarni yang berjudul Jender dan Feminisme $^{2}$ menjelaskan bahwa perempuan memiliki intuisi dan persepsi yang lebih tinggi dari lakilaki. Dari sifat tersebut membuat perempuan lebih pekat terhadap apa yang dirasakan dan dibutuhkan oleh masyarakat.

${ }^{2}$ Endang Sumiarni, Jendert dan Feminismer, Yogyakarta: Wonderful Publishing Company, 2004, hlm. 8
Indonesia sebagai penganut

system demokrasi modern juga

menerapkan konsep kesetaraan

gender baik dalam kehidupan

masyarakat maupun dalam politik

praktis . Hal tersebut dapat dilihat dari

kesetaraan antara laki-laki dan

perempuan dalam bidang sosial, hak

dalam mendapatkan pendidikan, bahkan

juga dalam politik praktis disini yang

dimaksud bukan hanya diberikan hak

untuk ikut memilih dalam pemilu, tetapi

juga hak untuk dipilih ke dalam kancah

politik tersebut. Pada Pemilu tahun

1999 misalnya Megawati terpilih

sebagai wakil presiden. Dilanjutkan pada tahun 2001 Megawati menjadi presiden menggantikan

Abdurrachman Wahid. Ini membuktikan bahwa perempuan sudah diberikan hak, dan ini merupakan embrio dalam perkembangan kesetaraan gender di Indonesia. ${ }^{3}$

\footnotetext{
3 Jurnal Politics : Jurnal Magister Ilmu Politik Universitas Hasanudin, Vol. 1, Number 1, Januari 2015.
} 
Meningkatnya

jumlah

perempuan yang masuk ke dalam

lembaga eksekutif turut membawa

dampak positif terhadap lembaga

legislative. Perempuan juga mulai

masuk ke ranah legislative sebagai actor politik .

Terkait dengan pemberian hak bagi perempuan untuk masuk ke dalam ranah public . Dari beberapa decade peraturan yang memuat pemberian hak politik terhadap perempuan yaitu pada tahun 2013. Undang-Undang tentang Pemilu khususnya Pasal 65 kemudian tahun 2008 berkaitan dengan peraturan pemilu , khususnya pasal 53 dan pasal 55, yang menyatakan anggota DPR, DPD dan DPRD memuat kuota $30 \%$ (tiga puluh persen) bagi perempuan $\left(\right.$ Pasal 53) ${ }^{4}$,

Pasal 55 ayat 2 yang memuat system zipper $^{5}$ yaitu bahwa setiap 3

4 Daftar bakal calon sebagaimana dimaksud dalam Pasal 52 Undang-Undang Nomor 8 tahun 2008 memuat paling sedikit 30\% (tiga puluh persen) keterwakilan perempuan.

${ }^{5}$ Di dalam daftar bakal calon sebagaimana dimaksud pada Undang-Undang Nomor 8 bakal calon terdapat sekurangkurangnya satu orang perempuan . Kemudian pada pemilu tahun 2019, yang mendasarkan pada UndangUndang No. 7 tahun 2017 ada penambahan pada panitia penyelenggara pemilihan umum juga keanggotaannya harus memperhatikan keterwakilan perempuan paling sedikit $30 \%$ (tiga puluh persen), seperti dalam pasal 10 , pasal 22, pasal 52 , dan pasal 59 dan beberapa pasal lain. Kebijakan ini untuk meminimalisir dominasi dari salah satu jenis kelamin dalam lembagalembaga politik yang merumuskan kebijakan publik .

\section{Kenyataan keunggulan}

perempuan dalam hal memimpin tidak perlu disangsikan. Banyak perempuan justru lebih mampu memimpin dibandingkan dengan lakilaki. Misalnya perempuan memiliki kelebihan untuk berpikir dan bernalar

tahun 2008 Pasal 55 ayat (1) dalam setiap 3 (tiga) orang bakal calon terdapat sekurangkurangnya 1 (satu) orang perempuan bakal calon. 
jauh ke depan. Perempuan pun memimpin dengan hati karena tidak dapat dipungkiri intuisi (gerakan hati) perempuan lebih pekat dan lebih bisa diandalkan dibandingkan dengan lakilaki sehingga hasilnya lebih optimal . Dibalik nama besar pimpinan laki-laki, justru ada perempuan -perempuan yang memegang peranan. Sungguh ironis, melihat jumlah perempuan yang lebih dominan di Indonesia (lebih dari 100 juta jiwa) tetapi justru peranan perempuan dalam dunia politik sangat rendah $^{6}$.

\section{Rendahnya keterwakilan} perempuan di bidang politik dikarenakan ada 2 faktor ${ }^{7}$ :

6 Eko Komariah Kuncoro, “Peningkatan Partisipasi Kaum Perempuan dalam Prosesproses Konstitusional dan Pemilu ", Laporan Konferensi: Memperkuat Partisipasi Politik Perempuan di Indonesia, Jakarta: 11 September 2002.

${ }^{7}$ Siti Nurul Hidayah, peneliti alumnus UIN Sunan Kalijaga, dalam women research institute, Promoting women leadership and inclusive, gender-based, and sustainable natural resource governance, 2014.
Pertama, Paradigma yang cenderung kuat di sebagian masyarakat Indonesia. Pemikiran ini memposisikan perempuan di pihak yang tidak memiliki otonomi dan kemandirian di segala bidang, termasuk politik. Karena pola pikir patriarkhi ini cenderung menempatkan perempuan di bawah kekuasaan laki-laki. Budaya patriarkhi ini sudah terlanjur melekat dan menjadi tradisi dan budaya turun temurun, lalu dianggap hal yang wajar . Bahkan perempuan yang nyaris sebagai korban budaya patriarkhi tersebut sering menerimanya sebagai kodrat . Budaya patriarkhi kian mendapat pembenarannya ketika penafsiran agama dalam banyak hal lebih berpihak pada kepentingan lakilaki.

Kedua, Komitmen tidak sepenuhnya dimiliki oleh institusi politik terhadap pemberdayaan perempuan . Misal dalam pengajuan bakal calon legislative perempuan, parpol seringkali melakukan demi 
memenuhi persyaratan pemilu . Selama ini hampir tidak ada langkah yang berarti dari parpol dalam hal mewujudkan pemberdayaan perempuan . Di level rekrutmen anggota dan kaderisasi , bagi parpol perempuan tetap menjadi pilihan kedua. Pada umumnya parpol merasa kurang yakin perempuan dapat menjadi vote getter dan menaikkan elektabilitas parpol.

$$
\text { Asumsi ini tentu berkaitan }
$$

dengan keterbatasan perempuan dalam kapital baik financial maupun sosial. Marjinalisasi yang terus berkembang inilah menjadikan perempuan cenderung tidak memiliki kemandirian politik $^{8}$.

Dipanggung politik baik lokal maupun nasional perempuan sering diposisikan sebagai objek bukan subyek. Sehingga partisipasi politik perempuan pun cenderung lebih rendah. Dari kenyataan tersebut maka muncul

\footnotetext{
${ }^{8}$ Harmona Daulay, Perempuan dalam Kmelut Jender, Medan : USU Press.
}

permasalahan yang diangkat yaitu : Bagaimana Pemilihan Umum anggota Parlement dalam perspektif kesetaraan dan keadilan gender ?

Metode Penelitian, Jenis penelitian ini adalah hukum empiris ${ }^{9}$, yaitu suatu cara atau prosedur yang digunakan untuk memecahkan masalah dengan terlebih dahulu meneliti data sekunder yang ada kemudian dilanjutkan dengan penelitian terhadap data primer di lapangan.

Sumber data dalam penelitian ini mendasarkan pada data primer dan sekunder. Data primer didapatkan melalui wawancara dengan responden. Data sekunder, yaitu data yang diperoleh dari penelitian kepustakaan yang berupa bahan-bahan hukum.

Dalam penelitian kualitatif , peneliti sangat erat kaitannya dengan faktor-faktor kontekstual , dan memulai dengan asumsi bahwa konteks itu kritis sehingga masing-masing konteks

\footnotetext{
${ }^{9}$ Soerjono Soekanto, Pengantar Penelitian Hukum, Cetakan Ketiga, Jakarta : UI Press, diperbarui 13 April 2019, hlm. 52
} 
ditangani dari segi konteks nya sendiri ${ }^{10}$ Sampling lebih bertujuan untuk menjaring sebanyak mungkin informasi dari berbagai macam sumber, sehingga informasi tersebut akan menjadi dasar dari rancangan dan teori yang muncul. Karena itu dalam penelitian ini sample (selanjutnya akan disebut dengan subjek) akan diambil secara tak acak (non random) dan disebut dengan "purposive-sample""

\section{Pembahasan}

\section{Konsep Pemilihan Umum,}

Gagasan demokrasi yang merujuk pada John Locke dan Rousseau, adanya jaminan kebebasan, keadilan, dan kesetaraan individu dalam segala bidang. Warga negara dan instrument negara pada level legislative , yudikatif dan eksekutif menjunjung tinggi nilai-nilai partisipasif dan kedaulatan untuk mewujudkan demokrasi. Hubungan antara warga

10 Poerwandari,E.K, 2013. Pendekatan Kualitatif Dalam Penelitian Psikologi, LPSP3 Fak.Psikologi UI Jakarta.

${ }^{11}$ Moleong,J.L. Metodologi Penelitian Kualitatif. PT Remaja Rosdakarya. Bandung. negara dengan negara dapat difasilitasi oleh berbagai lembaga dan elemen masyarakat karena adanya kebebasan bagi semua pihak untuk ikut serta secara aktif dalam pembangunan nasional. Masyarakat diberikan ruang untuk berperan aktif dan menjadi bagian dari proses demokrasi ${ }^{12}$

Partai politik yang merupakan motor bagi proses pemilihan umum di Indonesia dinilai masih bergerak lamban dan bahkan banyak yang masih menjadi pragmatis dalam menjalankan tanggung jawabnya sebagai lembaga politik seharusnya menciptakan kaderisasi yang sehat, baik dan mumpuni.

Tetapi dalam kenyataannya terutama negara berkembang idealisme tersebut tampak utopis . Partai politik dalam segi kaderisasi dalam mewujudkan visi misinya tenggelam pada "kekuasaan dan uang". Partai

\footnotetext{
${ }^{12}$ Norm Kelly dan Sefakor Ashiagbor, Partai Politik dan Demokrasi dalam Perspektif Teoritis dan Praktis. (Washington DC: National Democratic Institute., 2011). Hal. 3
} 
politik menjadi tumpul dalam menjalankan perannya baik secara internal terhadap kader maupun eksternal yakni public dan negara. Di Indonesia, partaip politik merupakan satu-satunya lembaga resmi yang diakui oleh undang-undang sebagai lembaga kader yang mampu mencalonkan kandidat pada kursi legislatif dan eksekutif. Tanggung jawab itulah yang menjadikan partai politik memiliki 'daya tawar yang besar dalam sebuah sistem demokrasi ${ }^{14}$. Daya tawar di sini mengarah kepada besarnya peran partai untuk bekerja dengan baik sehingga menciptakan kader yang siap dalam mengolah kekuasaan.

Pemilihan umum merupakan salah satu bagian dari proses sekaligus hasil dari sebuah sistem demokrasi . Meski demokrasi secara substansial dengan nilai-nilai yang menjunjung

14 Jurnal Politik Profetik, Volume 3 Nomor 1 Tahun 2014, 14. Alexander Wendt, Social Theory of International Relations, hlm. 229 tinggi keterbukaan, kebebasan dan hak asasi baru sepenuhnya dijalankan pasca runtuhnya kekuasaan Orde Baru di bawah Presiden Soeharto, Indonesia sendiri sebenarnya telah mengenal Pemilihan Umumt pertama sejak tahun 1955 hingga yang terakhir pada 2014 lalu. Pemilihan Umum yang pertama dilaksanakan pada masa Orde Baru ketika Presiden Soekarno menjabat dengan keikutsertaan empat partai besar yakni PNI, NU, PKI dan Masjumi serta beberapa partai kecil lainnya seperti Partai Katholik, Parkindo dan PSII. ${ }^{15}$ Setelah masa Pemilihan umum Orde Lama, Pemilihan Umum selanjutnya diadakan pada tahun 1971 ketika Orde Baru dengan keikutsertaan sepuluh partai $^{16}$. Setelah serangkaian pemilu yang 'dikuasai' oleh Orde Baru dengan hanya mengizinkan tiga partai

\footnotetext{
${ }^{15}$ Alfian, Pemikiran dan Perubahan Politik Indonesia, Jakarta: Gramedia, 1981,hlm.307.

${ }^{16}$ Rumah Pemilu.2014. "Gambaran Singkat Pemilihan Umum 2014". Diakses pada http://www.rumahpemilu.org/in/read/4030 Gambaran-Singkat-Pemilihan-Umum-2014di-Indonesia.
} 
yakni PPP, PDI dan Golkar. Fase reformasi membawa Indonesia pada Pemilu 1999, dimana partai dikembalikan pada fungsi awalnya. Kemudian diadakan kembali pada 2004 dengan perkembangan pada pola pemilihan presiden yang dilakukan secara langsung. Setelah pelaksanaan pemilu dengan sistem pemilihan presiden langsung, maka pada tahun 2009, diadakan kembali sistem pemilu yang sama dengan perbaikan pada beberapa kekurangan pada pemilu sebelumnya. Terakhir, pemilu diadakan pada April 2014 untuk pemilihan legislatif pusat dan daerah dan pada bulan Juli 2014 untuk pemilihan Presiden dengan berbagai perbaikan sebagai hasil dari evaluasi terhadap pemilu sebelumnya termasuk pada 2009 yang ternyata memendam banyak persoalan.

Sistem pemilihan umum di Indonesia didasarkan pada UndangUndang Dasar 1945 sebagai landasan utama dan undang-undang lainnya yang lebih terperinci yakni Undang-Undang 15 Tahun 2011 tentang Penyelenggara Pemilihan Umum, Undang-Undang 8 Tahun 2012 tentang Pemilihan Umum Anggota Dewan Perwakilan Rakyat, Dewan Perwakilan Daerah dan Dewan Perwakilan Rakyat Daerah , Undang -Undang no. 42 Tahun 2008 tentang Pemilihank Umum Presiden dan Wakil Presiden, Undang Undang $\quad 32$ Tahun 2004 tentang Pemerintahan Daerah (mencakup pemilu kepala daerah), Undang Undang no. 2 Tahun 2011 tentang Partai Politik, Undang-undang no. 27 Tahun 2009 tentang Majelis Permusyarawatan Rakyat, Dewan Perwakilan Rakyat Dewan Perwakilan Daerah, dan Dewan Perwakilan Rakyat Daerah ${ }^{16}$. Keseluruhan landasan hukum tersebut mencerminkan sistem demokrasi Indonesia yang telah tertanam dan terus diperbaharui.

Pada saat Pemilu tahun 1999 hingga tahun 2019, jumlah perempuan 
yang menjadi anggota DPR RI belum mencapai angka 30\% (tiga puluh persen). Pada Pemilu tahun 1999 jumlah perempuan yang menduduki kursi di DPR sebanyak 44 orang atau 8,8 persen. Proporsi ini meningkat 47,7 persen menjadi 65 orang pada pemilu tahun 2004 atau mendapat porsi sebesar 11,82 persen di DPR . Pada empat periode pemilu terakhir, keterwakilan perempuan tertinggi pada Pemilu tahun 2009, dengan proporsi sebesar 17,86 persen. Tetapi pada periode tahun 2014-2019, jumlah perempuan yang menjadi anggota DPR turun menjadi sebanyak 97 orang atau 17,32 persen dari total anggota DPR RI yang berjumlah 560 orang $^{17}$.

\section{Pemilu yang berkesetaraan}

dan berkeadilan gende, Sejak tahun 1990 melalui United Nation Development Program menyatakan

17 https://m.detik.com/news/kolom/d4174432/keterwakilan -perempuan-dalampolitik dalam jurnal Demokrasi, Tengku Rika Valentina, Affirmative Action untuk Demokrasi yang Berkeadilan Gender pada pemilu 2009, Vol. 9 No. 1, th. 2010. bahwa indicator untuk mengukur keberhasilan pembangunan suatu negara yaitu dengan Gender Development Index dan Gender Empowerment Measure $^{18}$.

GDI mengukur kesenjangan gender dalam pencapaian pembangunan manusia dengan memperhitungkan kesenjangan antara perempuan dan laki-laki di sana yang berdimensi dasar pembangunan manusia kesehatan, pengetahuan dan standar hidup menggunakan indicator komponen yang sama seperti pada Human Development Index

GDI adalah rasio HDI yang dihitung secara terpisah untuk Inggris dan menggunakan metodologi yang sama seperti dalam HDI. Ini adalah ukuran langsung dari kesenjangan gender yang menunjukkan HDI perempuan sebagai persentase dari HDI laki-laki ${ }^{19}$.

\footnotetext{
18 Megawangi, Ratna, 1999, Membiarkan Berbeda? Sudut Pandang Baru Tentang Relasi Gender, Mizan Pustaka, Bandung.

19 Ibid.,
} 
Sumber daya Pembangunan yang mempunyai potensi besar adalah kaum laki-laki dan perempuan di Indonesia. Hal ini dapat dilihat dari populasi perempuan yang hampir imbang dengan laki-laki yaitu 130,3 juta perempuan dan 131,6 juta laki-laki ( sensus penduduk 2017 ) tahun 2019 terdiri dari 133,4 juta perempuan dan 134,7 juta laki-laki ( sensus penduduk 2019 ).

Hal ini menunjukkan betapa besarnya peranan kaum perempuan di Indonesia. Potensi kaum perempuan telah sejak lama diakui Pemerintah Indonesia. Oleh karena itu, sejak orde baru dilakukan berbagai upaya untuk meningkatkan partisipasi kaum perempuan dalam pembangunan antara $\operatorname{lain}^{20}$ :

Menetapkan

dan

melaksanakan berbagai program pemberdayaan perempuan

sebagaimana tercantum dalam GBHN

20 Heriyani Agustina, 2009, Keterwakilan Perempuan di Parlemen dalam Perspektif Keadilan dan Kesetaraan Gender, Tiara Wacana, Yogyakarta, hlm. 168. dan Program Pembangunan Nasional

( Propenas ). Menetapkan peraturan perundang-undangan yang lebih berpihak pada kaum perempuan , seperti Inpres Nomor 9 tahun 2000 tentang pengarusutamaan Gender dalam Pembangunan Nasional. Membentuk Kementrian Negara Urusan Peranan Wanita sejak orde baru dan sampai saat ini tetap eksis dengan nama Kementrian Negara Pemberdayaan Perempuan . Mendirikan organisasi sebagai wadah partisipasi perempuan seperti Dharma Wanita PKK, dan berbagai LSM. Membentuk Departemen Kewanitaan dalam struktur organisasi partai politik . Berbagai advokasi dalam berbagai media yang dlakukan oleh LSM-LSM. Wanita Indonesia memiliki peranan dalam pembangunan di bidang politik, baik terlibat dalam kepartaian , legislative , maupun dalam pemerintahan. Partisipasi dalam bidang politik ini tidaklah semata-mata hanya sekedar pelengkap saja melainkan harus 
berperan aktif didalam pengambilan keputusan politik yang menyangkut kepentingan kesinambungan negara dan bangsa.

Meski demikian banyak yang meragukan kalau kenaikan proporsi itu sejalan dengan semakin tingginya perhatian terhadap persoalan yang dihadapi perempuan di Indonesia.

Salah satunya Undang -
Undang Ketenagakerjaan walaupun
ada perwakilan perempuan di DPR
tetapi dengan lahirnya Undang -
Undang itu tidak memberikan
perlindungan terhadap buruh
perempuan dan menunjukkan
ketidakmampuan pemahaman membuat
kebijakan. Hal ini merupakan suatu
kelemahan bagi partai yang hanya
menjaring politisi perempuan dan
juga laki-laki yang dianggap hanya
"terkenal" (selebritis) meski tidak
memahami issu massa. Jadi ini
merupakan realita yang sangat
memprihatinkan dalam kondisi Pemilu
di Indonesia. Elektabilitas

diterjemahkan partai yaitu harus terkenal (populer) atau kuat secara financial bukan dari segi kapasitas atau kapabilitas maupun ketrampilan . Dalam hal ini perlu adanya capacity building, untuk saat ini masih pada level propaganda, level pidato-pidato, belum menyentuh menambah ketrampilan berpolitik .

Hal inilah yang berdampak salah satunya keterwakilan perempuan di parlemen (DPR ) masih tetap memprihatinkanb, tidak seimbang dengan partisipasi pemilih perempuanp dan populasi penduduk perempuanp. Harapan untuk meningkatkan keterwakilan perempuan di DPR memang terbuka lebar. Hal ini karena telah ditetapkannya UndangUndang Nomor 7 tahun 2017 tentang Pemilu menyatakan Anggota DPR, DPD, dan DPRD yang antara lain menetapkan kuota minimal 30\% untuk perempuan.

Ketentuan tersebut dipenuhi dengan partai politi (parpol) dengan 


\begin{abstract}
menempatkan caleg perempuan secara zipper yaitu dari tiga orang caleg, satu diantaranya adalah perempuan . Namun tidak semua parpol dapat memenuhi kuota minimal 30\% karena minimnya kaderkader perempuan yang berkualitas sebagai caleg .
\end{abstract}

Hal ini berdampak pada kendala , persepsi dan konstruksi sosial yang telah mensubordinasi perempuan di bawah laki-laki yang pada akhirnya akan menghambat kaderisasi perempuan di dalam tubuh parpol. Tidak jarang banyak parpol yang setengah hati mengajukan caleg perempuan karena adanya persepsi dan konstruksi sosial yang keliru tersebut. Kalaupun ada parpol yang mengajukan namun disertai dengan keterpaksaan atau asal-asalan karena adanya tuntutan undang-undang dan minimnya kader caleg perempuan yang berkualitas .

Pengajuan minimal $30 \%$ caleg perempuan oleh partai politik pun tidak otomatis akan mewujudkan keterwakilan perempuan dengan persentase yang sama di parlemen . Penyebab tidak lain karena caleg dengan "nomor urut jadi" ternyata masih di dominasi laki-laki. Oleh karena itu banyak pihak yang pesimis keterwakilan perempuan di DPR tahun 2019-2024 nanti akan meningkat secara signifikan. Untuk mewujudkan hal itu diperlukan proses dan penantian yang cukup panjang.

\section{Perbandingan} dengan negara -negara lain, Di Indonesia system pemilunya seperti ini berbeda dengan negara lain seperti : Negara Rwanda. Parlemen Rwanda terdiri atas dua kamar. Parlemen membuat undangundang dan diamanatkan oleh konstitusi untuk mengawasi kegiatan Presiden dan Kabinet. Majelis rendah adalah Dewan Perwakilan, yang terdiri dari 80 anggota yang menjabat selama lima tahun. Dua puluh empat dari jabatan tersebut disiapkan khusus untuk perempuan, yang dipilih melalui 
majelis pejabat pemerintahan daerah gabungan; tiga kursi lain disiapkan untuk anak muda dan orang cacat; 53 kursi sisanya dipilih melalui hak pilih universal dibawah system perwakilan proposional . Setelah pemilihan umum tahun 2008, terdapat 45 perwakilan perempuan, sehingga menjadikan Rwanda satu-satunya negara yang mayoritas anggota parlemennya perempuan . Majelis tinggi adalah Senat, yang terdiri dari 26 kursi. Anggota dipilih oleh berbagai lembaga. Minimal tiga puluh persen senator haruslah perempuan ${ }^{21}$

Pasca Genosida Rwanda pada tahun 1994, Rwanda adalah pemimpin besar dalam mengembangkan kesetaraan gender. Pada lebih dari satu decade reformasi dalam bidang politik dan arena legislative telah menempatkan pemberdayaan perempuan pada garis 21 Rwanda, diunduh dari https://id.wikipedia.org/wiki/Rwanda\#CITE REFCJCR2003, 20 Juli 2015 dalam buku Dessy Artina, Keterwakilan Politik Perempuan di Beberapa Negara, Best Publisher (Anggota Ikapi), Yogyakarta, 2016, hlm. 48. depan prioritas pemerintah dan memberikan perempuan di Rwanda hak yang meyakinkan.

Perubahan pada matrimonial, warisan dan hukum tanah telah menjadi hak untuk perempuan sejak terciptanya pemerintahan sementara pasca genosida, sebelumnya perempuan hanya dianggap sebagai hiasan dan buruh dalam kehidupan mereka. Tidak seperti di banyak negara tetangga, hukum baru mengesampingkan hukum adat yang seringkali diabaikan hak asasi milik perempuan . Keterwakilan perempuan dalam pemerintahan yang dapat dijadikan contoh pada semua tingkat pemerintah : 49 persen pada majelis rendah parlemen, 30 persen di senat, 44 persen di Pengadilan Tinggi; dan 40 persen propinsi diatur oleh perempuan ${ }^{22}$.

\footnotetext{
${ }^{22}$ Government of Rwanda and FIAS, Sources of Informal Activity in Rwanda, Washington, DC diunduh dari www.africon.mil sebagaimana dikutip Eky Nanda Nuzulul, Peranan Perempuan Rwanda Dalam Proses Perdamaian Pasca Genosida 1994, Skripsi, Jurusan Ilmu Hubungan Internasional, Fisipol, Universitas Pembangunan Nasional "Veteran”, Yogyakarta, 2011, hlm. 49.
} 
Periode transisi selama tahun 1994-2003, keterwakilan perempuan dalam parlemen mencapai 25,73 persen. Pemilihan parlemen yang dilaksanakan pada September 2003 menandakan bahwa periode transisi pasca genosida telah berakhir, yang telah memberikan ruang kebebasan bagi perempuan pada masa kejayaan. Dengan perempuan mendapatkan 49\% kursi di lower house dan $30 \%$ kursi di upper house, telah menjadikan total hampir $50 \%$ total keterwakilan mereka di lembaga pemerintahan ${ }^{23}$.

Arab Saudi, yang selama ini terkenal sebagai negara dengan tidak adanya keterwakilan perempuan yang duduk di lembaga negara akhirnya akan membuka ruang bagi perempuan untuk menduduki posisi pimpinan di Dewan Syuro, yaitu sebuah badan tinggi negara di Arab Saudi. Dewan Syuro bertugas memberikan saran kepada pemerintah

\footnotetext{
23 Vanessa Far (2000), Woman Combatan and The Mobiliztion, Disarmament and reintegration Process in Rwanda, New York, seperti dikutip Dessy Artina, Keterwakilan Politik Perempuan di Beberapa Negara, Best Publisher (Anggota Ikapi), Yogyakarta, 2016, hlm. 49
}

untuk membentuk undang-undang. Dewan akan ditunjuk Raja untuk memberikan ulasan hukum dan menjawab pertanyaan dari para menteri. Raja Abdullah, sebagai pemimpin Arab Saudi, memutuskan bahwa Dewan Syuro harus memiliki $20 \%$ keanggotaan perempuan, yaitu sekitar 30 orang $^{24}$.Dan pada 19 februari 2013 lalu, Raja Abdullah akhirnya melantik 30 orang yang akan menduduki posisi dewan Syuro bersama dengan 130 anggota Dewan syuro laki-laki. Salah satu anggota Dewan Syuro, Thuraya Obaid, mengatakan bahwa tantangan utama yang sedang dihadapi adalah menunjukkan bahwa perempuan Saudi mampu turut serta mengambil tanggung jawab bangsa sebagaimana laki-laki. Keputusan Raja Abdullah ini diharapkan menjadi titik perubahan untuk

24 Khanifah, "Keterwakilan Perempuan di Arab Saudi", http://www.jurnalperempuan.org/keterwak ilan-perempuan-di-arab-saudi.html,4 Februari 2016 dalam buku Dessy Artina, Keterwakilan Politik Perempuan di Beberapa Negara, Best Publisher (Anggota Ikapi), Yogyakarta, 2016, hlm. 83 
kehidupan yang lebih baik bagi perempuan-perempuan di Arab Saudi yang selama ini dibatasi, misalnya tidak boleh menyetir mobil sendiri, tidak boleh bekerja, tidak boleh membuka rekening bank sendiri tanpa seizin walinya dan begitu banyak pembatasan dan diskriminasi lainnya.

\section{PENUTUP}

Perbedaan gender (konstruksi sosial) adalah salah satu penyebab keterwakilan perempuan di parlemen timpang bukan disebabkan oleh perbedaan (sex /kodrat atau takdir). Hal ini karena adanya persepsi dan konstruksi sosial yang menutup akses kaum perempuan untuk banyak berkiprah dalam bidang politik . Keterwakilan perempuan di parlemen dapat diubah dan ditingkatkan meskipun perlu proses yang panjang. Keterwakilan perempuan di parlemen jangan hanya di lihat dari segi kuantitas dari banyaknya perempuan yang menjadi anggota DPR tetapi harus dilihat dari kualitas yang memadai. Hal ini akan sulit terwujud selama parpol tidak memiliki kader perempuan yang berkualitas seperti yang terjadi selama ini. Oleh karena itu parpol harus membuka peluang kaderisasi yang adil dan terbuka bagi perempuan .

Konvensi PBB tentang Hak-hak Politik Perempuan (diratifikasi dengan Undang-Undang Nomor 68 Tahun 1958 tentang Pengesahan Konvensi tentang Hak-Hak Politik Perempuan (The Convention on Political Rights for Women) dan konvensi PBB tentang Penghapusan Segala bentuk Diskriminasi terhadap Perempuan/ Convention on The Elimination of All Forms of Discrimination against Women? CEDAW (diratifikasi dengan Undang-Undang Nomor 7 tahun 1984 tentang Pengesahan Konvensi mengenai Penghapusan Segala Bentuk Diskriminasi terhadap Wanita) Oleh karena itu perempuan perlu mengaktualisasikan dirinya dengan berpartisipasi dalam lembaga-lembaga 
politik ( eksekutif, legislative, yudikatif)

maupun dalam kehidupan politik.

$$
\text { Tingkat keterwakilan }
$$

perempuan di dunia meningkat setiap

tahunnya, berdasarkan data terakhir dari

Interp Parliamentary Union tentang

Women in National Parliaments terutama dari beberapa negara baik itu dengan system pemerintahan Presidensial maupun dari negara dengan system pemerintahan Parlementer . Dalam rangka mendorong partisipasi perempuan dalam pembangunan perlu makin dikembangkan kegiatan perempuan , melalui peningkatan penguasaan ilmu pengetahuan dan teknologi, keterampilan, serta ketahanan mental dan spiritual agar dapat lebih memanfaatkan kesempatan berperan aktif di segala bidang kehidupan bangsa dan dalam segenap kegiatan pembangunan.

\section{DAFTAR PUSTAKA}

Ahmad H. Silaban, Implementasip Politikh Perempuanm di Kota
Makasarn, dalam Jurnal Politics : Jurnal Magister Ilmu Politik Universitas Hasanudin, Vol. 1, Number 1, Januari 2015.

Alfian, Pemikiran dan Perubahan Politik Indonesia, Jakarta: Gramedia, 1981,hlm.307.

Endang Sumiarni, Jendert dan Feminismer, Yogyakarta: Wonderful Publishing Company, 2004, hlm. 8

Jurnal Politics : Jurnal Magister Ilmu Politik Universitas Hasanudin, Vol. 1, Number 1, Januari 2015.

Daftar bakal calon sebagaimana dimaksud dalam Pasal 52 UndangUndang Nomor 8 tahun 2008 memuat paling sedikit $30 \%$ (tiga puluh persen) keterwakilan perempuan.

Di dalam daftar bakal calon sebagaimana dimaksud pada UndangUndang

Nomor 8 tahun 2008 Pasal 55 ayat (1) dalam setiap 3 (tiga) orang bakal calon terdapat sekurang-kurangnya 1(satu) orang perempuan bakal calon.

Eko Komariah Kuncoro, "Peningkatan Partisipasip Kaum Perempuanm dalam Proses-proses Konstitusionalk dan Pemilup", Laporan Konferensi: Memperkuat Partisipasip Politikh Perempuanp di Indonesia, Jakarta: 11 September 2002.

Siti Nurul Hidayah, peneliti alumnus UIN Sunan Kalijaga, dalam women research institute, Promoting women leadership and inclusive, gender-based, and sustainable natural resource governance, 2014.

Harmona Daulay, Perempuan dalam Kmelut Jender, Medan : USU Press.

Soerjono Soekanto, Pengantar Penelitian Hukum, Cetakan Ketiga, 
Jakarta : UI Press, diperbarui 13 April 2019, hlm. 52

Poerwandari,E.K, 2013. Pendekatan Kualitatif Dalam Penelitian Psikologi, LPSP3 Fak.Psikologi UI Jakarta.

Moleong,J.L. Metodologi Penelitian Kualitatif. PT Remaja Rosdakarya. Bandung.

Norm Kelly dan Sefakor Ashiagbor, Partai Politikh dan Demokrasip dalam Perspektifg Teoritish dan Praktis. (Washington DC: National Democratic Institute., 2011). Hal. 3

Jurnal Politik Profetik, Volume 3 Nomor 1 Tahun 2014

Rumah Pemilu.2014. "Gambaran Singkat Pemilihan Umum 2014”. Diakses pada http://www.rumahpemilu.org/in/read/40 30/Gambaran-Singkat-PemilihanUmum-2014-di-Indonesia.

https://m.detik.com/news/kolom/d4174432/keterwakilan -perempuandalam-politik dalam jurnal Demokrasi, Tengku Rika Valentina, Affirmative Action untuk Demokrasi yang Berkeadilan Gender pada pemilu 2009, Vol. 9 No. 1, th. 2010.

Megawangi, Ratna, 1999, Membiarkan Berbeda? Sudut Pandang Baru Tentang Relasi Gender, Mizan Pustaka, Bandung.

Heriyani Agustina, 2009, Keterwakilan Perempuan di Parlemen dalam Perspektif Keadilan dan Kesetaraan Gender, Tiara Wacana, Yogyakarta, hlm. 168.

Rwanda, diunduh dari https://id.wikipedia.org/wiki/Rwanda\#C ITEREFCJCR2003, 20 Juli 2015 dalam buku Dessy Artina, Keterwakilan Politik Perempuan di Beberapa Negara, Best Publisher (Anggota Ikapi), Yogyakarta, 2016, hlm. 48.
Government of Rwanda and FIAS, Sources of Informal Activity in Rwanda, Washington, DC diunduh dari www.africon.mil sebagaimana dikutip Eky Nanda Nuzulul, Peranan Perempuan Rwanda Dalam Proses Perdamaian Pasca Genosida 1994, Skripsi, Jurusan Ilmu Hubungan Internasional, Fisipol, Universitas Pembangunan Nasional "Veteran", Yogyakarta, 2011, hlm. 49.

Vanessa Far (2000), Woman Combatan and The Mobiliztion, Disarmament and reintegration Process in Rwanda, New York, seperti dikutip Dessy Artina, Keterwakilan Politik Perempuan di Beberapa Negara, Best Publisher (Anggota Ikapi), Yogyakarta, 2016, hlm. 49

Khanifah, "Keterwakilan Perempuan di Arab Saudi", http://www.jurnalperempuan.org/keterw akilan-perempuan-di-arab-saudi.html,4 Februari 2016 dalam buku Dessy Artina, Keterwakilan Politik Perempuan di Beberapa Negara, Best Publisher (Anggota Ikapi), Yogyakarta, 2016, hlm. 83 